\title{
Virological and serological aspects of hepatitis B and the delta agent
}

\author{
G Hess
}

\begin{abstract}
The hepatitis B virus (HBV) belongs to a group of viruses termed hepadnaviruses. The $3.2 \mathrm{~kb}$ genome encodes for a variety of proteins involved in viral replication (p-gene), transactivation (x-gene), or encodes for structural proteins (c- and s-genes). Several viral and non-viral functions determine the clinical course of HBV infection. The hepatitis $D$ virus resembles a viroid and requires the $\mathrm{HBV}$ as a helper virus. The interaction between the viruses is not well understood. More information on the interaction between the human host and viruses is needed to help improve the treatment.

(Gut 1993; supplement: S1-S5)
\end{abstract}

Five identified and at least two additional unidentified agents may be responsible for the clinical features of acute hepatitis. Identified agents have been termed viruses $A, B, C, D$, and $\mathrm{E}$. Whereas chronic disease courses have not been reported in hepatitis $A$ and $E$, chronicity occurs at different rates in hepatitis B, C, and D. The clinical features linked to viral persistence are highly variable and span from asymptomatic subjects with normal liver enzyme activities to patients with progressive liver disease. ${ }^{1}$ Serious late outcomes of chronicity include liver cirrhosis and primary liver cell carcinoma. ${ }^{12}$ This review concentrates on virological and serological aspects of hepatitis B and the delta agent with special emphasis on their clinical significance.

\section{Hepatitis B virus}

THE HEPADNA VIRUS FAMILY

The hepatitis B virus (HBV) belongs to a group of viruses that has been termed hepadna viruses. Other members of this virus family include the woodchuck hepatitis virus (WHV), the ground squirrel hepatitis virus (GSHV), and the duck hepatitis virus (DHV). Hepadna viruses have also been found in tree squirrels and in herons. Hepadna viruses share common characteristics and represent animal models with which to study $\mathrm{HBV}^{3}$

\footnotetext{
Boehringer Mannheim, Mannheim, Germany G Hess

Correspondence to: G Hess,

The sera of people with HBV contain three morphological forms expressing the hepatitis B surface antigen (HBsAg) (Fig 1). The complete infectious HBV (Dane particle) represents a spherical $42 \mathrm{~nm}$ particle containing a circular, partly double stranded
DNA, shelled by the hepatitis $\mathrm{B}$ core antigen (HBcAg) and by HBsAg (Fig 2). Spherical and filamentous HBsAg particles represent viral coat material produced in excess by the infected hepatocyte. ${ }^{4}$ They expose only HBsAg. In addition, sera may contain hepatitis $B$ e antigen ( $\mathrm{HBeAg}) . \mathrm{HBeAg}$ is not particle associated and circulates in a soluble form in the sera of viraemic subjects infected with $\mathrm{HBV} .^{4}$

THE HBV GENOME

HBV contains a small amount of DNA, approximately $3.2 \mathrm{~kb}$ in size (Fig 3$){ }^{4-6}$ Four open reading frames have been identified and termed $\mathrm{p}, \mathrm{x}, \mathrm{c}$, and s-genes. Three initiation sites within the $s$ gene result in the formation of three different hepatitis B surface proteins and their glycosylated forms. ${ }^{4}$ The small surface protein corresponds to the s-gene and is 24000 and 27000 Daltons in size in its nonglycosylated and glycosylated forms, respectively. P33 and gp36 correspond to the middle protein that is derived from the pre-S2 and s-genes. The large surface protein corresponds to p39 and gp42 and represents a product of pre-S1, pre-S2 and the s-gene. ${ }^{4}$ The various surface polypeptides are not equally distributed in all morphological HBsAg forms, with the large surface protein predominantly present in the complete virion (Fig 2). Pre-S2 contains a binding site for modified albumin, ${ }^{7}$ and pre-S1 is believed to expose a site that can attach to hepatocyctes. ${ }^{8}$ Therefore, pre-S proteins may play a role in the attachment of the HBV to the hepatocyte.

Subtype determinants that are mutually exclusive have also been found on HBsAg. Two pairs have been identified which, for the most part, are mutually exclusive and have

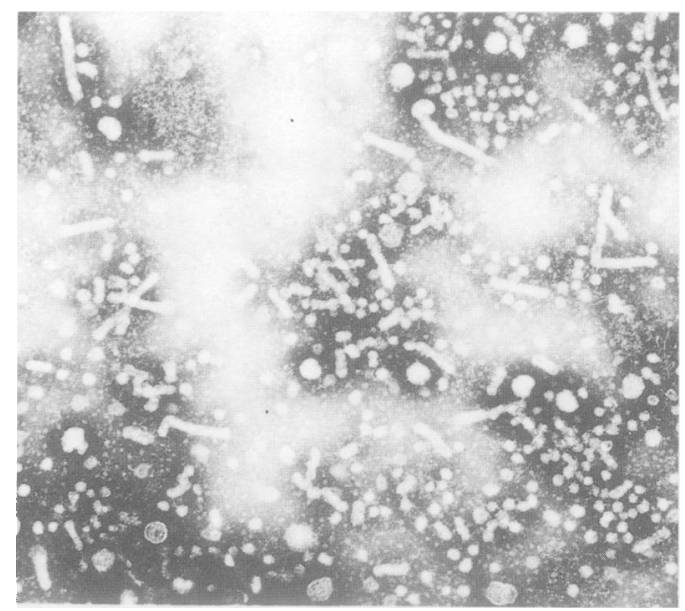

Figure 1 Electronmicrograph of serum of an $\mathrm{HBs} A \mathrm{~g}$ carrier exhibiting complete virions and spherical and filamentous HBs Ag form 


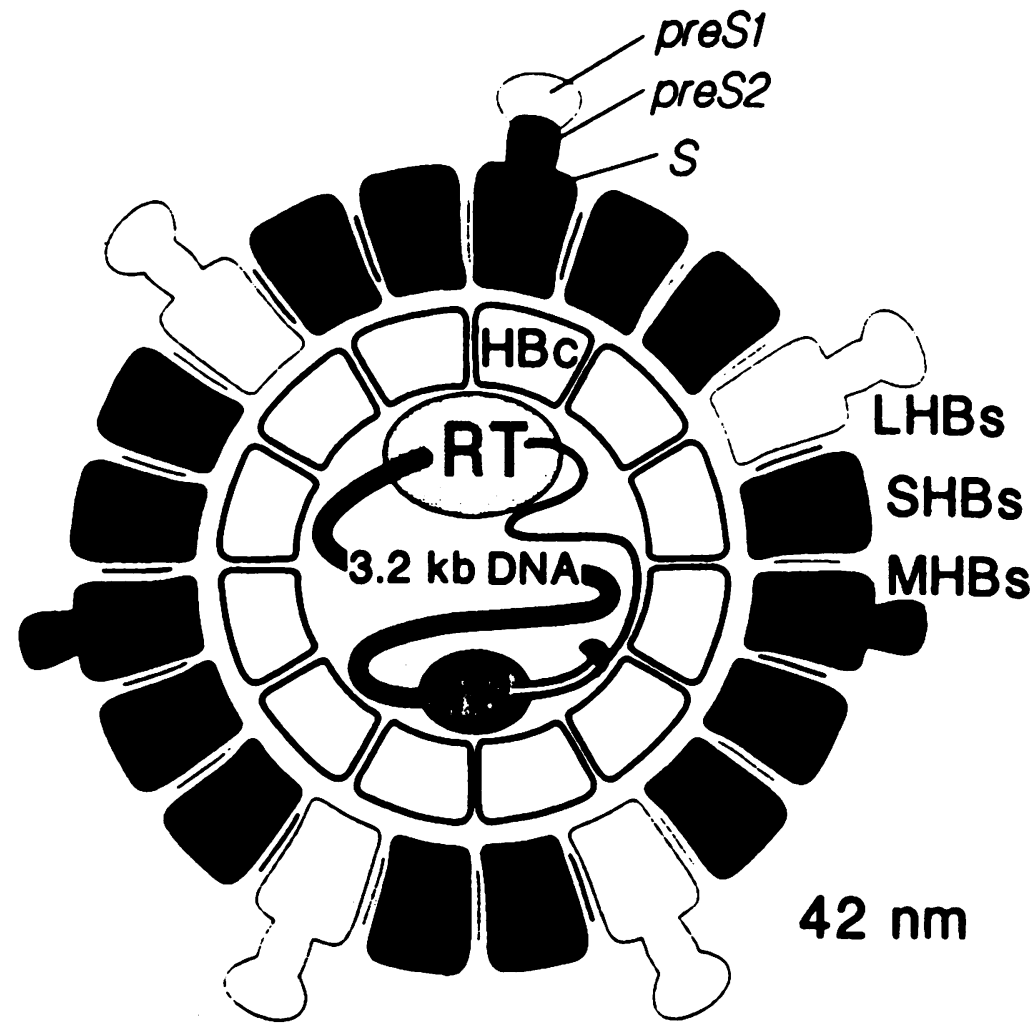

Figure 2 Model of the hepatitis B virus. LHBs, MHBs, and SHBs (large, middle and small hepatitis $B$ surface proteins); $S$ (S-domain); preS2 (preS2 domain); preS1 (preS1 domuin); HBc, (hepatitis B core protein); RT (reverse transcriptase) (which is probably identical with the endogenous DNA polymerase); and TP ( 5 ' terminal protein of the DNA minus strand) (which is probably identical to the primer of reverse transcription).

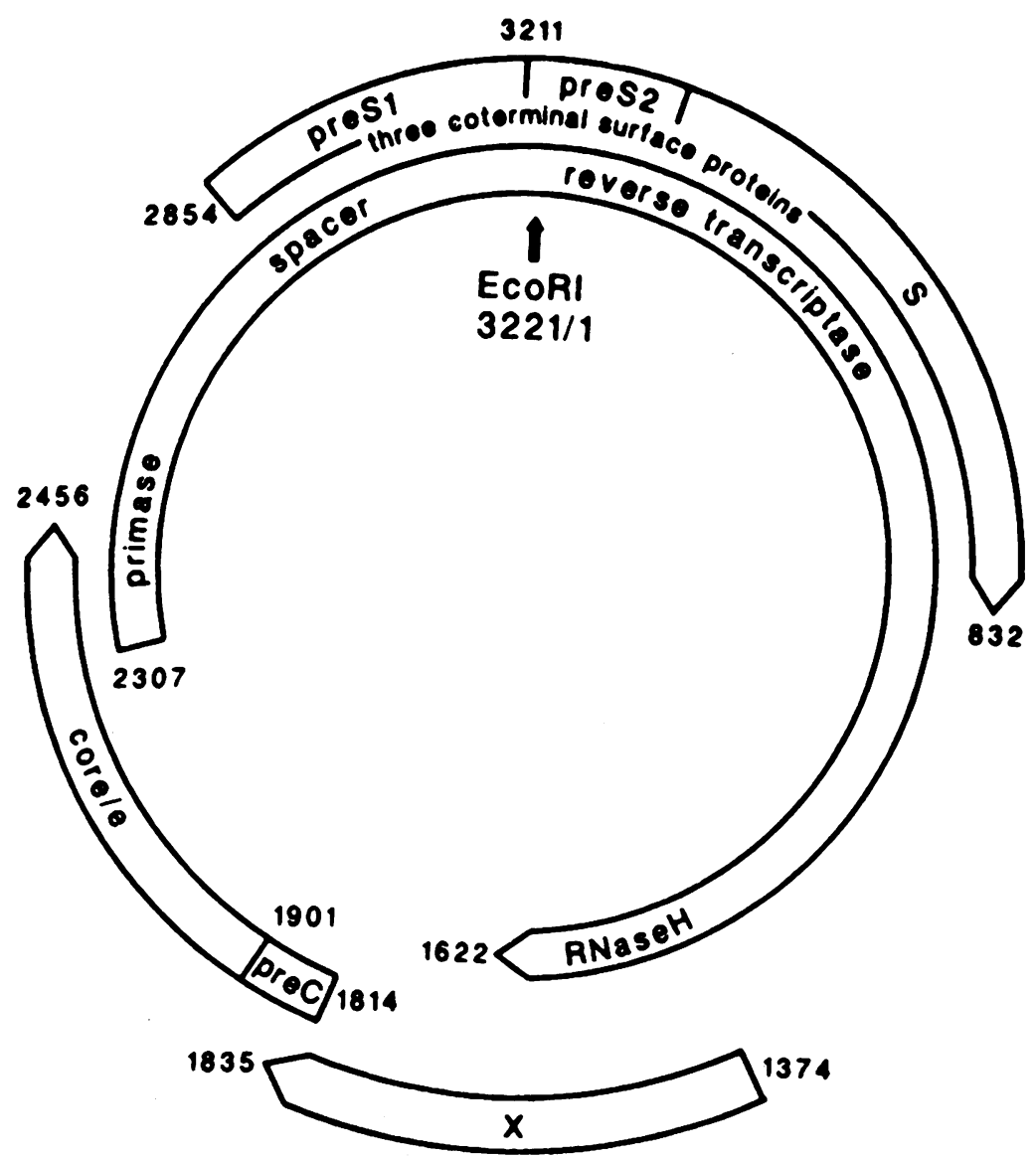

Figure 3 Schematic presentation of the complete virion. $R T=$ reverse transcriptase, $T P=$ terminal protein. been termed $d / y$ and $w / r$. Additional subtype determinants have also been described, and a common determinant ' $a$ ' is seen on all $\mathrm{HBsAg}$ forms. HBsAg subtypes allow the study of epidemiological patterns of HBV infection.

The c-gene is preceded by the pre- $\mathrm{C}$ region. $\mathrm{HBcAg}$ and HBeAg are both derived from the same gene. The carboxyterminal 34 amino acids of the c-gene product are arginine rich, thus highly basic and believed to bind DNA. ${ }^{9}$ The first 19 amino acids of the pre-C region are a signal peptide for insertion of the nascent p 25 polypeptide into the endoplasmic reticulum. The signal peptidase of the endoplasmic reticulum cleaves the signal peptide. Mutations in the pre-C region may lead to inactive pre-C regions resulting in continuous $\mathrm{HBV}$ replication but the failure to produce and express soluble $\mathrm{HBeAg}{ }^{4}$

The p-gene encodes for the viral DNA polymerase, which also functions as a reverse transcriptase by encoding the protein primer for reverse transcription, and as a spacer and RNase $\mathrm{H}$ (Fig 3). ${ }^{4}$ The reverse transcriptase of the $\mathrm{HBV}$ is, however, fundamentally different from that of HIV in that it does not contain an integrase.

The function of the $x$-gene is not well understood, although its role in transactivation is well established. ${ }^{1}$ It may also modulate the production of $\beta$ interferon. ${ }^{4}{ }^{10}$

HBV REPLICATION

Figure 4 summarises the replication strategy of HBV. The mechanism for the attachment of HBV to the hepatocyte remains obscure, although evidence suggests that pre-S proteins may play a role. ${ }^{78}$ Production of a complete virion begins with the conversion of RNA (+) to DNA (-) by reverse transcription. DNA (+) is produced after primer translocation. ${ }^{11}$ Assembly of the viral coat is followed by two alternative pathways, either excretion or retransport to the nucleus. There is evidence that this process contributes to the maintenance of $\mathrm{HBV}$ infection. Integration of parts of the viral genome occurs during $\mathrm{HBV}$ infection, ${ }^{11} 12$ although the exact mode of integration is not known.

HBV does not replicate exclusively in the hepatocyte. Virus replication in mononuclear cells is of potential importance in the maintenance of infection or reactivation.

CHRONICITY OF HBV INFECTION

Although there is some evidence that ccc DNA may contribute to chronicity, epidemiological factors suggest that host rather than viral factors are responsible for chronicity. ${ }^{13}$ The mechanism involved in the spontaneous loss of viral replication in chronically infected individuals remains even more obscure.

PATHOLOGICAL AND CELLULAR EFFECTS OF HBV In general, epidemiological evidence suggests that liver cell injury correlates with viral replication and immunocompetence. There- 


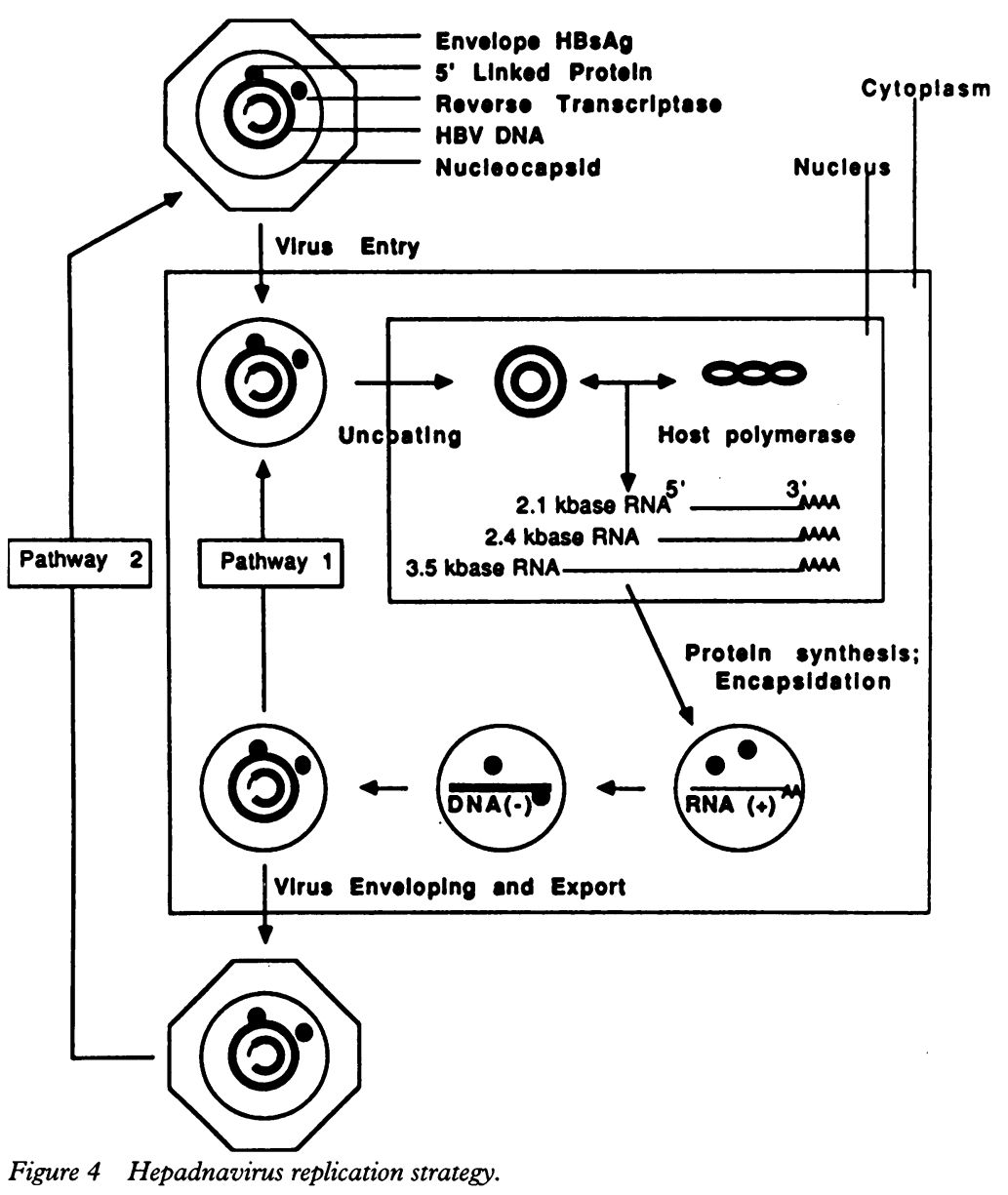

fore, $T$ cell responses to hepatitis $B$ antigens exposed on liver cells are believed to play a key role in liver injury. ${ }^{14}$ However, there is still a role for cytopathic effects, as has been shown by the accumulation of pre-S1 proteins in transgenic mice. ${ }^{15}$

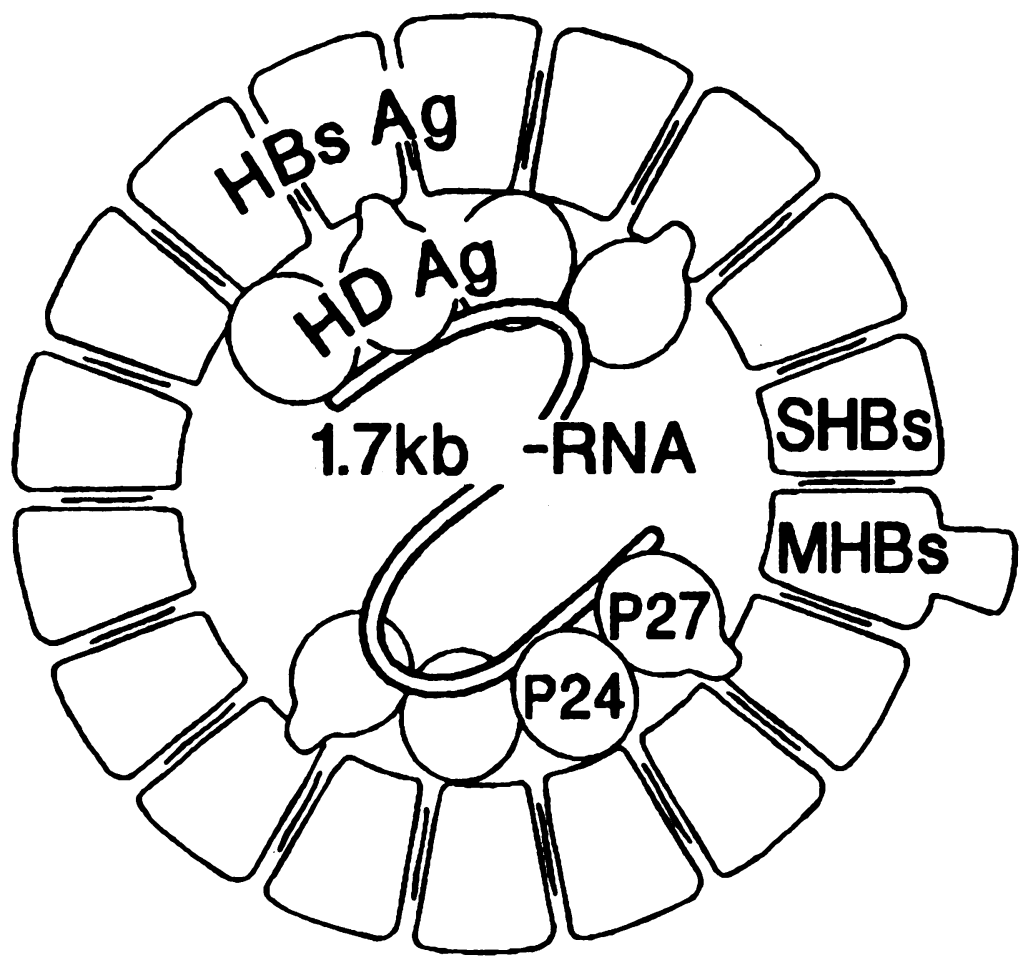

Figure 5 Composition of the hepatitis $D$ virus containing a single-stranded $R N A$ and $H D V$-encoded delta antigen ( $\mathrm{HD}-\mathrm{Ag}$ ) with polypeptides of 24000 and $27000 \mathrm{Da}$. The $H D V$ shell is derived from $H B V$.
HEPATOCELLULAR CARCINOMA AND HBV

Hepatocellular carcinoma (HCC) has been linked epidemiologically to HBV infection. ${ }^{2}$ In addition, integrated HBV-DNA has been found in most HCC with, and in some cases without, serological evidence of HBV infection. Integration of parts of the HBVDNA into the host genome may change the function of hepatitis B proteins and may contribute significantly to the development of HCC. ${ }^{12}$ Other potential factors include $x$-gene expression, resulting in the expression of oncogenes or transcription factors, ${ }^{16}$ or the generation of oxidants by inflammatory cells and other factors (for example, aflatoxins).

\section{Hepatitis delta virus}

The hepatitis delta virus (HDV) cannot be assigned to any of the known groups of viruses, and closely resembles a viroid. ${ }^{17} \mathrm{HCV}$ replicates only in the presence of $\mathrm{HBV}$, which functions as a helper virus for HDV. ${ }^{18}$

ULTRASTRUCTURE OF THE HDV

$\mathrm{HDV}$ is a spherical particle of $36 \mathrm{~nm}$ in diameter (Fig 5). A small $1.7 \mathrm{~kb}$ single stranded RNA is shelled by the delta antigen. The outer coat of $\mathrm{HDV}$ is derived from the hepatitis B virus. However, the surface of HDV differs from that of HBV in its composition of small, middle, and large surface proteins. ${ }^{4}$ This difference does not affect the infectivity of HDV. Particles that can be seen in sera of patients infected with $\mathrm{HBV}$ are also detected in individuals infected with HDV.

THE HDV GENOME

Figure 6 illustrates the HDV genome. HDVRNA encodes the delta antigen, consisting of two polypeptides of 24000 and 27000 Daltons. Sequences encoding basic proteins have been identified and are believed to function as an RNA binding domain. In addition, a putative nuclear localisation signal has been described (Fig 6). ${ }^{12-21}$

HDV REPLICATION

Replication of HDV follows the rolling cycle mechanism, with both genomic and antigenomic RNA as a result of self cleavage and self ligation under certain conditions (Fig 7). ${ }^{1822}$ The genomic RNA is approximately 10 fold more abundant than the antigenomic RNA. A single infected liver cell may contain as many as 300000 copies of HDV-RNA, primarily within the nucleus. Antigenomic RNA within the cytoplasm is believed to be responsible for delta antigen production.

The interaction between $\mathrm{HBV}$ and HDV replication remains obscure. However, it has become clear that HBsAg synthesis is sufficient to allow HDV production. ${ }^{23}$ In cases of superinfection of an $\mathrm{HBsAg}$ carrier with $\mathrm{HDV}$, HBV synthesis is frequently shut down and the HDV acquires the subtype of the pre-existing HBV infection. 


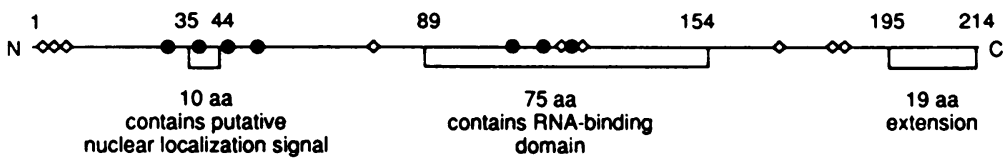

Figure 6 Primary structure of the delta antigen. The small and large forms of the delta antigens are comprised of 195 and 214 amino acids, respectively, and differ only in terms of the 19-amino acid extension at the carboxy terminus.

CHRONICITY OF HDV INFECTION

Chronicity of HDV infection varies significantly. Coinfection with $\mathrm{HBV}$ and $\mathrm{HDV}$ frequently resolves whereas superinfection of an $\mathrm{HBsAg}$ carrier with HDV frequently results in chronicity. Host rather than viral factors may be considered more important for chronicity. ${ }^{24}$

\section{PATHOLOGICAL AND CELLULAR EFFECTS OF} HDV

In most cases, the mode of liver cell injury is considered to be cytopathic, potentially caused by molecular interactions between $\mathrm{HBV}$ and HDV, as seen in plant viruses. ${ }^{24}$ Apparently healthy HDV carriers, however, have been observed. ${ }^{25}$ This suggests that viral factors associated with genetic heterogeneity of HDV may have an impact on the pathogenicity. In addition, autoimmune reactions associated with HDV infection need to be considered in the pathogenesis of the HDV infection.

\section{HDV AND HCC}

HCC is rare in people infected with HDV. This is probably explained by the rapid progression of HDV to cirrhosis and liver failure. In general, the time frame will not allow evolution of primary liver carcinoma.

\section{GENOME}
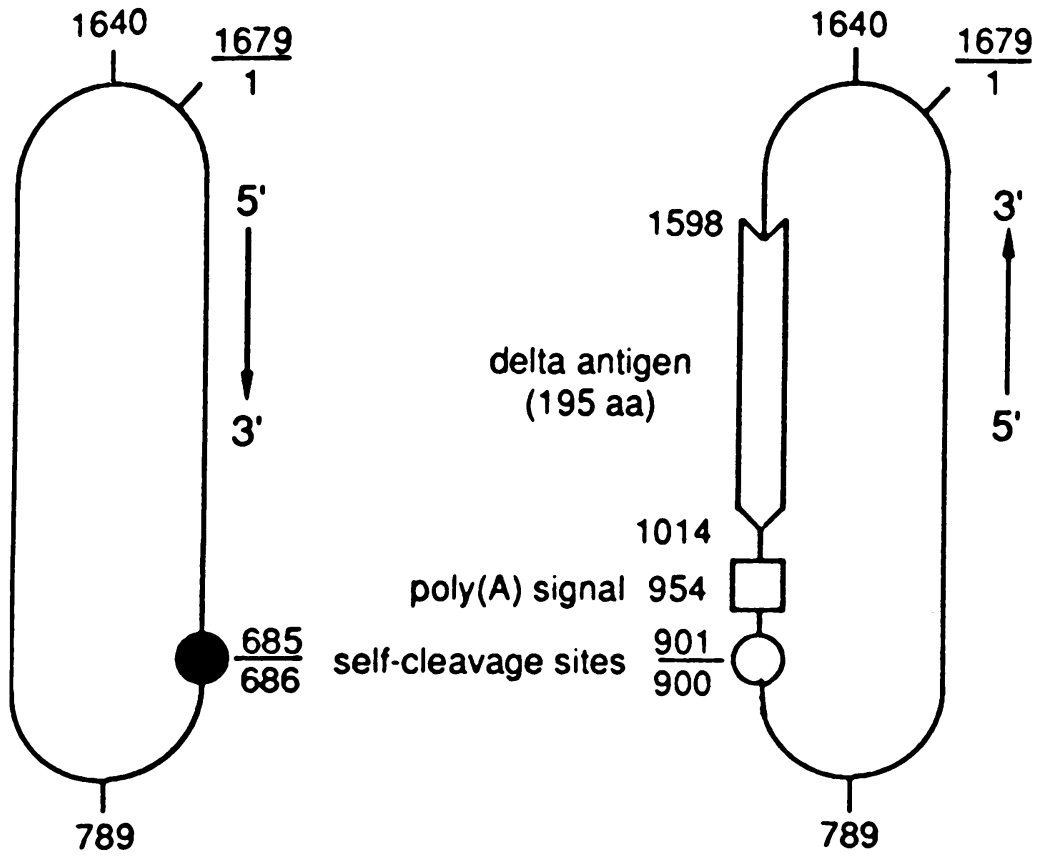

Figure 7 Organisation of the hepatitis D virus genome and antigenome.

\section{Discussion}

In recent years, much has been learned about the structure, replication, and function of $\mathrm{HBV}$ and the delta agent. Most of the information comes from in vitro studies and, to some extent, from animal models. However, not all these models reflect the interaction of the virus and the human host to a sufficient extent. Thus, many of the studies targeting liver injury rely on observations in defined clinical settings. ${ }^{15} 24$ This teaches us that although much progress has been made in the understanding of $\mathrm{HBV}$ and $\mathrm{HDV}$, important information is still missing. ${ }^{3412} 1824$ The interaction of the human host with $\mathrm{HBV}$ and HDV deserves increasing attention in the years to come. It is both the understanding of the viruses themselves and their interaction with the host that will potentially give new clues to the treatment of disease.

1 Perrillo R. Treatment of chronic hepatitis B. In: Hollinger FB, Lemon SM, Margolis HS, eds. Viral hepatitis and liver disease. Baltimore: Williams and Wilkins, 1991: 616-23.

2 Beasley RP, Hwang LY. Overview on the epidemiology of the hepatocellular carcinoma. In: Hollinger FB, Lemon SM, Margolis HS, eds. Viral hepatitis and liver disease. Baltimore: Williams and Wilkins, 1991: 532-35.

3 Robinson WS. Hepadnaviridae and their replication. In: Fields BN, Knipe DM, eds. Fields virology (Vol 2). New York: Raven Press, 1990: 2137-69.

4 Gerlich WH, Heermann KH. Functions of hepatitis B virus protein and virus assembly. In: Hollinger FB, Lemon SM, Margolis HS, eds Viral hepatitis and liver disease. Baltimore: Williams and Wilkins, 1991: 121-34.

5 Tiollais P, Pourcel C, Dejean A. The hepatitis B virus. Nature 1985; 317: 489-95.

6 Ganem D, Varmus HE. The molecular biology of the hepatitis B virus. Ann Rev Biochem 1987; 56: 651-93.

7 Machida A, Kishimoto S, Ohnuma $\mathrm{H}$, et al. A polypeptide containing 55 amino acid residues coded by the pre-S region of hepatitis $B$ virus deoxyribonucleic acid bears the receptor for polymerized human as well as chimpanzee albumins. Gastroenterology 1984; 86: 910-18.

8 Pontisso P, Petit MA, Bankowski MJ, Peeples ME. Human liver plasma membranes contain receptors for the hepatitis $B$ virus pre-S1 region and, via polymerized human serum albumin, for the pre-S2 region. 7 Virol 1989; 63: 1981-88.

9 Gallina A, Benelli F, Rindi G, Muttini M, Milanesi G. A recombinant hepatitis $B$ core antigen polypeptide with the protamine-like domain deleted self-assembles into capsid particles but fails to bind nucleic acids. ₹ Virol 1989; 63: particles

10 Yen TSB, Mitchell PJ, Seto E. Mechanism of transcriptional trans-activation by the hepatitis $B$ virus $x$ protein. In Hollinger FB, Lemon SM, Margolis HS, eds. Viral hepatitis and liver disease. Baltimore: Williams and Wilkins, 1991: 186-89.

11 Wu TT, Condreay LD, Liu C, Mason W, Jilbert AR. Hepadnavirus DNA synthesis. In: Hollinger FB, Lemon SM, Margolis HS, eds. Viral hepatitis and liver disease. Baltimore: Williams and Wilkins, 1991: 114-21.

12 Tuttleman J, Pourcel C, Summers J. Formation of the pool of covalently closed circular viral DNA in hepadnavirus infected cells. Cell 1986; 47: 451-60.

13 Stiehm R. Immunologic basis for chronicity of hepatitis $B$ virus infection in neonates. In: Hollinger FB, Lemon SM, Margolis HS, eds. Viral hepatitis and liver disease. Margolis HS, eds. Viral hepatitis and hiver

14 Eddleston ALW. Overview of HBV pathogenesis. In: Hollinger FB, Lemon SM, Margolis HS, eds. Viral hepatitis and liver disease. Baltimore: Williams and Wilkins, 1991: 234-37.

5 Yu M, Finlayson J, Shih JWK. Interaction between various polymerized human albumins and hepatitis B surfaceantigen. $\mathcal{F}$ Virol 1985; 55: 736-43.

16 Balsano C, Avantaggiati ML, Natoli G, et al. Transactivation of $\mathrm{c}$-fos and c-myc protooncogenes of the HBV-x protein. In: Hollinger FB, Lemon SM, Margolis HS eds Viral hepatitis and liver disease. Baltimore: Williams and Wilkins, 1991: 572-76.

17 Koshy R, Meyer M, Kekule AS, Lauer U, Caselmann WH, Hofschneider PH. Altered function of hepatitis B virus proteins as a consequence of viral DNA integration may pead to hepatocyte transformaton. In: Hollinger FB, Lemon SM, Margolis HS, eds. Viral hepatitis and liver disease. Baltimore: Williams and Wikns, 1991: 566-72.

18 Taylor JM, Chao M, Hsieh S-Y, Ryu WS. Structure and replication of hepatitis delta virus. In: Hollinger FB, Lemon SM, Margolis HS, eds. Viral hepatitis and liver disease. Baltimore: Williams and Wilkins, 1991: 460-63. 
19 Makino S, Chang M-F, Shieh C-K, et al. Molecular cloning and sequencing of a human hepatitis delta virus RNA. Nature 1987; 329: 343-46.

20 Chang M-F, Baker SC, Soe LH, et al. Human hepatitis delta antigen is a nuclear phosphoprotein with RNA binding activity. F Virol 1988; 62: 2403-10.

21 Lai MMC, Chao Y-C, Chang M-F, Lin J-H, Gust I. Functional studies of hepatitis delta antigen and delta virus RNA. In: Gerin JL, Purcell RH, Rizzetto $M$, eds. The hepatitis delta virus. New York: Alan R Liss, 1991: 283-92.

22 Sharmeen L, Kuo MY-P, Dinter-Gottlieb G, Taylor J. The antigenomic RNA of human hepatitis delta virus can undergo self-cleavage. $\mathcal{F}$ Virol 1988; 62: 2674-79.
23 Sureau C, Moriarty AM, Thornton GB, Lanford RE Production of infectious hepatitis delta virus in vitro and neutralization with antibodies directed against hepatitis B virus pre-S antigens. $\mathcal{F}$ Virol 1992; 66: 1241-45.

virus pre-S antigens. F Virol 1992; 66: $1241-45$.
24 Negro F, Rizzetto M. Pathobiology of hepatitis delta virus. In: Hollinger FB, Lemon SM, Margolis HS, eds. Viral hepatitis and liver disease. Baltimore: Williams and Wilkins, 1991: 477-80.

25 Hadzyiannis SJ, Hatzakis A, Papaionnou C, Anastassakos $C$, Vassiliadis E. Endemic hepatitis delta virus infection in a Greek community. In: Gerin JL, Purcell RH, Rizzetto $\mathrm{M}$, eds. The hepatitis delta virus. New York: Alan $\mathrm{R}$ Liss, 1991: 181-202. 